\title{
Comparing Archaeological Proxies for Long-term Population Patterns: An Example from Central Italy
}

\author{
Alessio Palmisano ${ }^{1}$, Andrew Bevan ${ }^{1}$, and Stephen Shennan ${ }^{1}$ \\ 1. Institute of Archaeology, University College London
}

\begin{abstract}
Raw counts of archaeological sites, estimates of changing settlement size and summed radiocarbon probability distributions have all become popular ways to investigate long-term regional trends in human population. Nevertheless, these three archaeological proxies have rarely been compared. This paper therefore explores the strengths and weaknesses of different kinds of archaeological evidence for population patterns, as well as how they address related issues such as taphonomic loss, chronological uncertainty and uneven sampling. Our overall substantive goal is to reconstruct demographic fluctuations in central Italy from the Late Mesolithic to the fall of the Roman Empire (7500 BC-AD 500), and with this in mind, we bring to bear an unusually detailed and extensive dataset of published central Italian archaeological surveys, consisting of some 10,971 occupation phases at 7,383 different sites. The comparative results demonstrate reassuring consistency in the suggested demographic patterns, and where such patterns diverge across different proxies (e.g. Late Bronze Age/Iron Age) they often do so in useful ways that suggest changes in population structure such as site nucleation or dispersal.
\end{abstract}

\section{Keywords}

demography, summed probability distributions, radiocarbon, aoristic methods, Mediterranean, archaeological survey, settlement patterns

\section{Introduction}

Over the past decade or so, there has been renewed archaeological interest in demographic reconstruction, in close step with other trends, such as the growing popularity of both cultural evolutionary and human ecological frameworks. The role of population size as a driver of cultural change was perhaps first emphasised by social anthropologists (Naroll 1956, Carneiro 1962) and then adopted by archaeologists to explain long-term variation in subsistence-settlement systems (Binford 1968; Sanders and Price 1968; Shennan 2000, 2001) or shifts in sociopolitical complexity (Feinman and Neitzel 1984; Feinman 2011). More recent studies, in Europe for example, have stressed the upward-impact of Neolithic economies on local population densities (Shennan and Edinborough 2007; Shennan 2009; Shennan et al. 2013) from the often-lower population levels present when hunter-gatherers were active in the same region. Such discussions also feed into ongoing debate about whether agricultural innovation and intensification typically develops in response to population growth or vice versa (Boserup 1965; Cohen 1977; Netting 1993; Peregrine 2004), while a range of separate research continues to emphasise how population growth in a given landscape has typically run in step with increasingly substantial cultural modifications, often in a clearly coupled human demographic-ecological system (see Butlin and Roberts 1995; Allen 2001; Mercuri et al. 2002; Fyfe et al. 2010; Walsh 2013; Langutt et al. 2016; Wigand and McCallum 2017).

With this wider background in mind, it is clear that successful characterisation of human population fluctuations over the longue durée (and assessment of the causes of these fluctuations) is pivotal for 
how we understand cultural and environmental change. While genetic (both modern and ancient) or palaeodemographic (osteological) estimates of changing population size are also important (e.g. Bocquet-Appel 2002, Cassidy et al. 2015), the most popular archaeological proxies for investigating regional demographies over the long-run have been data on counts of archaeological sites, sometimes with accompanying estimates of changing settlement size, and the summed probability distributions of radiocarbon dates (hereafter SPD). The first two have a longer archaeological pedigree in being used to estimate population across many different regional contexts (Sanders 1965; Adams 1965 and 1981; Wright and Johnson 1975; Sanders et al. 1979). More recently, over the past two decades, SPDs of archaeological (i.e. anthropogenic) radiocarbon dates have also become popular especially for inferring population in prehistoric periods (Rick 1987; Shennan and and Edinborough 2007; Bocquet-Appel et al. 2009; Shennan et al. 2013; Downey et al. 2014; Timpson et al. 2014; Balsera et al. 2015; Crema et al. 2016) and for assessing demographic responses to climate change (Weninger et al. 2009; Williams et al. 2010; Maher et al. 2011; Woodbridge et al. 2014; Flohr et al. 2016). Nevertheless, these proxies are rarely compared directly. Building on previous work (e.g. Tallavaara et al. 2010; French 2015; French and Collins 2015; Demjan and Dreslerová 2016), we advocate greater use of multiple lines of demographic evidence and here present a comparison of radiocarbon SPDs and various modelled treatments of settlement counts and sizes for central Italy from the Late Mesolithic (7500 BC) to the fall of the Roman Empire (AD 500).

Estimating past population has generally been considered a problematic goal by most archaeologists, but the past couple of decades has seen a slow resurgence of interest in reconstructing demographic variables. Population estimates build on the assumption that an observable density of archaeological evidence over time and across a study region is somehow proportional to population despite the presence of certain archaeological biases (Drennan et al. $2015,11)$. Put simply, the bigger the population, the stronger the signal in the archaeological record (e.g. the higher the density of pottery sherds, stone tools, site counts, radiocarbon dates, etc.). Hence, the first step in modelling population dynamics over the long-term is to identify those archaeological materials that might provide the most reliable indirect measures of population, and exclude those more strongly affected by other factors. Furthermore, it is usually assumed that such indicators do not offer good evidence for absolute numbers of people in the past, but rather offer an idea of relative intensities of population and proportional change through time (Tallavaara et al. 2010, 252; Drennan et al. 2015, 12). In this work, we use three types of archaeological data as proxies for estimating population fluctuations over the long run: 1) Settlement data including site counts; 2) summed estimated settlement sizes, effectively a weighted version of site counts; and 3) SPDs of radiocarbon dates. Two main potential issues common to three lines of evidence relate to the presence of both research and taphonomic biases, which can negatively affect the density and visibility of the archaeological signal known in a given region. For example, all archaeological periods are not necessarily equally represented in either settlement data or radiocarbon date lists, due to a series of factors: 1) the research priorities of different archaeological excavations and surveys resulting in specific periods being better investigated than others; 2) variation in the field methods adopted; and 3) the enhanced visibility of particular diagnostic artefacts that are easier to detect and collect. In addition, the archaeological record has been shaped by a wide variety of natural and cultural taphonomic processes (e.g. agriculture, erosion, alluviation, post-depositional deposits, human and animal excavations, wind deflation, etc.; cf. Roper 1976, 372; Hirth 1978, 125; Ammerman 1985, 33; Gregg et al. 1991; Brantingham et al. 2007). Several studies have argued that a broad gradient exists in which there is increasing taphonomic loss with increasing time depth, or put another way, a higher level of destruction of earlier archaeological deposits (Surovell and Brantingham 2007; Surovell et al. 2009), leaving them underrepresented when compared with the more recent deposits. 
Turning more specifically to settlement evidence, a "site count" approach to population inference is typically based on the assumption that the overall number of sites is representative of population across space and time, but such counts can of course be biased by the intensity of archaeological surveys carried out in a given region (Plog et al. 1978; Cherry 1983), by the ease with which a given site type can be observed and discovered archaeologically, etc. In addition, it is sometimes difficult to distinguish settlements from other kinds of site (e.g. cemeteries, specialized ritual sites, temporary agricultural or hunting installations), and, even if we can do so, to decide what kinds of site should be part of the counting exercise. A further issue is is that we struggle to date the creation, duration and abandonment of sites and, without the support of stratigraphic data and/or calibrated radiocarbon dates, a given site's profile of occupational intensity through time can be only established by rough assessment of the stylistic chronologies of artefacts recovered from it. We are similarly left uncertain about the relative permanence vs seasonality of site use or about whether there is exact contemporaneity among multiple sites across a wider landscape. The spatial structure and size hierarchies of settlement sites are a further key variable that is often poorly understood. For example, a simple site count rarely does justice to changing population levels where a settlement system exhibits a move towards growing concentration of people in a few larger centres and we have to be able to observe large, contiguous spatial regions of settlement to understand how such a nucleation process plays out. Paying attention to estimates (from survey and excavation) of site size is therefore a useful addition to site counts, and typically rests on the assumption that the number of inhabitants is somehow proportional to the area of a settlement. Nonetheless, this correlation is neither likely to scale in a linear way (e.g. larger cities are often also more densely packed, albeit with less inhabited, functionally specialist zones as well) nor to be universally consistent across different regions of the world (Drennan et al. 2015, 20-25).

Turning to radiocarbon dates, large lists of archaeological radiocarbon dates can be calibrated and counted up (summed in the manner of a histogram) as a proxy for population, based on the assumption that the more people living in a given region, the more the archaeological deposits, the more organic materials, and the more radiocarbon samples collected and dated (Rick 1987). Although this approach has been widely used by archaeologists for estimating population fluctuations for the Paleolithic and the Neolithic, it faces several challenges, in addition to the general ones discussed above, which may undermine its validity (Williams 2012; Contreras and Meadows 2014; Torfing 2015). First, radiocarbon samples are often strategically collected for dating stratigraphic sequences within a site and, therefore, are not a random sample of human activity in every phase. Second, both the instrumental error associated with each date and the radiocarbon calibration curve have effects on the shape of each calibrated date's probability distribution and hence on the SPD of all summed calibrated dates (Michczyński and Michczyński 2006, 4; Williams 2012, 581-584; Weninger et al. 2015). Third, research budgets can determine the extent to which radiocarbon samples are collected and used in an archaeological excavation, so some regions are richer in collected dates than others. Finally, certain chronological periods are more likely to be sampled than others: if datable coins, documents or fine-ware pottery exist, for instance, there is typically greater reliance on these forms of chronological evidence and less interest in paying for expensive radiocarbon dates.

Although the SPD of radiocarbon dates, site counts, and estimated settlement sizes have been widely used as proxies for population, the above limitations point to a need for cross-comparison among them where possible to strengthen our overall interpretation of demographic trends through time. The resolutions of these different kinds of evidence vary as well: an SPD of radiocarbon dates usually provides better chronological resolution, but typically less geographical coverage and control over sampling quality, when compared with site counts and estimated site sizes, but the 
latter are usually time-sliced to a much coarser level of resolution. For sites, there is a further imbalance between the kinds of evidence produced by extensive and methodical archaeological excavation in a given region, versus use of archaeological surface survey data. In what follows, we will therefore make use of a series of both well-established and novel statistical techniques to compare these different lines of evidence and mitigate some of their individual limitations.

\section{Settlement and Population in Central Italy}

Central Italy's long history of extensive archaeological excavations and systematic survey projects make this region an unusually privileged case study for assessing demographic trends and in what follows we have chosen to focus on the period from the Late Mesolithic (7500 BC) to the fall of the Roman Empire (500 AD; see Table 1 for the chronological scheme). The portion of central Italy examined here covers around 50,000 sq.km, encompassing present-day Tuscany, Lazio, and a small part of western Umbria (Fig. 1). This region can be divided into three main geographical units that, moving from west to east, include a landscape of plains and low hills, and the mountain ranges of the Anti-Appennines and Appennines (Barker and Stoddart 1994, 146-149). During the early and middle Holocene, the Middle Tyrrhenian coast was a landscape of intermittent sand dunes, lagoons, and marshy areas, which changed substantially during the Middle Bronze Age (Attema et al. 2010, 35-40). The inland area of central Italy (roughly matching with Tuscany) is dominated by a hilly landscape (e.g. Volterra, Chianti, the Sabatini and Albani hills) with a few fertile plains. The Apennines cover the eastern edge of our study area and provide upland pasture at an altitude ranging between 1000 and $2000 \mathrm{~m}$. The fertile valleys and low hills of central Italy, frequently separated by a network of several rivers running in both an east-west and north-south direction, provided a suitable area for dense settlement and population, from which most of the archaeological evidence has been recovered.

Human settlement in central Italy during the Mesolithic is most evident in a series of caves, rock shelters and open air sites distributed from the lowlands of the Tyrrhenian coast to the mountain ranges of the Apennines. Mixed food production strategies of foraging, hunting and fishing appear likely in the Late Mesolithic, as do seasonal patterns of lowland-upland movement (Barker 1975; Martini 2001; Tozzi 2012). The first Neolithic settlements appeared in central-western Italy during the first half of the 6th millennium BC, especially in the lowlands close to rivers and lakes (Malone 2003, 257-259; Robb 2007, 25). The arrival of farming in this phase is believed to have brought a rapid and substantial increase in population, with communities permanently residing in houses and villages, supported by a mixed economy of hunting, farming and small-scale herding (Barker 1975, 144-147; Robb 2007, 26). During the Middle and Late Neolithic, farming strategies became more intensive, with greater evidence for the production and consumption of cereals and legumes, of mixed livestock (but a prevalence of cattle), and less evidence than before for hunted red deer and wild boar (Fugazzola Delpino et al. 1993; Anzidei and Zarattini 2007, 89). The central Italian Eneolithic (third millennium BC) sees a further apparent increase in site number, with some now exceeding one hectare in size (Anzidei and Carboni 2009, 94-95; Anzidei et al. 2010) and demographic growth thereafter appears to have continued during the Early (2300-1700 BC) and Middle Bronze Age (1700 - 1325/1300 BC), at least in Etruria and Latium (Peroni and di Gennaro 1986). Middle Bronze Age settlements were located across both the lowlands and highlands and continue to be sustained by a mixed economy based on intensive agriculture and animal husbandry (Peroni 1996, 202-204; Costantini and Costantini Biasini 2007). In contrast, during the Late Bronze Age $(1325 / 1300-1020 / 950 \mathrm{BC})$ there is a marked abandonment of the lowlands, with a switch to settlements mainly on hilltops and other naturally defended locations (Barker and Stoddart 1994, 154). Further radical changes in settlement patterning then occur between the Final Bronze Age $(1175 / 1150$ - 1020/950 BC) and the Early Iron Age (1020/950 -750/725 BC) with the abandonment of many of the smaller-sized dispersed hilltop villages (those generally about 2-3 ha in size) and the 
concentration of population in larger nucleated and centralized urban centres (sometimes measuring over $100 \mathrm{ha}$ ) located in the lowlands and on plateaus (Peroni 2000; Fulminante 2014, 44-47; Alessandri 2015 and 2016;). By the later Iron Age and Archaic period, this process becomes a fullscale urbanisation episode, with the political landscape fragmented into several city-states located an average of 15-25 km apart (Cifani 2002; Vanzetti 2002; Fulminante 2014, 207-212; Redhouse and Stoddart 2011; Stoddart 2016). During the third century BC, these central Italian 'peer polities' become amalgamated into a larger, unified state under the power of Rome (Di Giuseppe 2005, 1060). By the late Republican Period (first century BC) there is further increase in the overall number of settlements peaking by the mid-second century AD (Witcher 2005 and 2008). Thereafter, archaeological data suggest a gradual decrease of the population of central Italy from the second half of the second century AD until the fall of the Roman Empire in the 5th century AD (Lewit 1991; Scheidel 2002; Turchin and Nefedov 2009, 213-216).

\begin{tabular}{|l|l|l|}
\hline \multicolumn{1}{|c|}{ Period } & \multicolumn{1}{|c|}{ Absolute dates } \\
\hline Mesolithic & $10,000 / 9,500-6000 / 5800 \mathrm{BC}$ \\
\hline Early Neolithic & $6000 / 5800-4500 \mathrm{BC}$ & \\
\hline Middle Neolithic & $4500-3500 \mathrm{BC}$ & \\
\hline Late Neolithic & $3500-3000 \mathrm{BC}$ \\
\hline Eneolithic & $3000-2300$ & \\
\hline Early Bronze Age & $2300-1700 \mathrm{BC}$ & \\
\hline Middle Bronze Age & $1700-1325 / 1300 \mathrm{BC}$ & \\
\hline Recent Bronze Age & $1325 / 1300-1175 / 1150 \mathrm{BC}$ & Late Bronze \\
\hline Final Bronze Age & $1175 / 1150-1020 / 950 \mathrm{BC}$ & Age \\
\hline Early Iron Age & $1020 / 950-750 / 725 \mathrm{BC}$ & \\
\hline Late Iron Age (Orientalizing Age) & $750 / 725-580 \mathrm{BC}$ & \\
\hline Archaic Period & $580-480 \mathrm{BC}$ & \\
\hline Post-Archaic Period & $480-350 \mathrm{BC}$ & \\
\hline Republican Period & $350-30 \mathrm{BC}$ & \\
\hline Early Imperial Period & $30 \mathrm{BC}-100 \mathrm{AD}$ \\
\hline Mid-Imperial Period & $100-300 \mathrm{AD}$ \\
\hline Late Imperial Period & $300-500 \mathrm{AD}$ & \\
\hline
\end{tabular}

Table 1. A chronological scheme for central Italy (after Guidi and Piperno 1993, Plate VI and X; Malone 2003, Table I; Attema et al. 2010, Table 2.1; Rajala 2013, Table 1; Fulminante 2014, Table 7; Alessandri 2016, Fig.2).

The above brief overview of settlement change represents a qualitative assessment of current opinion drawn from the existing literature, and the following discussion now looks to compare it with a more quantified treatment via close attention to radiocarbon dates, site counts and estimated site sizes. To produce the latter datasets, we have sought to work as exhaustively as we could through existing online databases and both electronic and print publications to create two georeferenced databases, one for sites and one for radiocarbon dates (see Fig. 1). A total of 726 uncalibrated radiocarbon dates have been identified from 171 sites and either harmonised from existing online databases in some cases (BANADORA, RADON, University of Oxford's ORAU, EUROEVOL) or, more often added from a wide range of publications (for a slightly wider chronological range to avoid edge effects, Fig.1a). This number of dates exceeds the suggested minimum threshold of 200-500 dates to produce a reliable SPD for a time interval of 10,000 years, although certain concerns about sample size will still be discussed below (Michczyńska and Pazdur 2004; Michczyńska et al. 2007; Williams 2012, 580-581). All of these radiocarbon dates are from archaeological contexts, with the majority being samples of bone, charcoal and wood. Radiocarbon dates obtained from marine samples such as shell have been removed (and are not part of the above 
total) to avoid the complicated issues arrising from unknown or poorly understood marine reservoir offsets.

To create the database of archaeological sites in central Italy, the lead author conducted a comprehensive review, standardisation, and synthesis of settlement data from reports and gazetteers relating to 59 different archaeological surveys of varying intensity across ca.10,000 sq.km (Fig. 1b). Settlement data have been recorded, where possible, as georeferenced polygons per time-slice (unprojected WGS84, with each slice having a 200-year resolution where possible) and when the former was impossible, as circular buffers based on published estimates of site size per time-slice (dataset available online, Palmisano et al 2017). This allows us to assess changes in site location and extent, wider spatial configurations of sites in the landscape and regional site size hierarchies. One major caveat is that it was only possible to estimate site sizes per phase for those larger multiperiod sites that had also been extensively excavated and/or surveyed methodically. A total of 7,383 sites and 10,971 occupation phases have been collected using the above approach (many sites were occupied in multiple periods). In addition, the very uncertain or fuzzy definitions of site function provided by many publications (e.g. the ambiguity of the assumption that every site is a settlement) urges further interpretative caution (cf. Gallant 1986; Wandsnider 1998). As noted above, sites not only refer to dwelling places, but can refer to temporary activity areas (e.g. campsites), industrial zones (mines), and cemeteries. For the purposes of this paper, however, we have chosen to deal exclusively with those places identified as human habitation sites or possible habitations, and hereafter then use the terms site and settlement interchangeably to refer to this subset.

\section{Methods}

\subsection{Radiocarbon summed probability distributions}

The method used in this paper to aggregate radiocarbon dates builds largely on previous work that seeks to test observed SPDs of radiocarbon dates against theoretical null models and/or under permutation (Shennan et al. 2013, Timpson et al. 2014; Crema et al. 2016), and to address issues such as "wealth-bias" of particular site phases (Timpson et al. 2014), the effect of taphonomic siteloss through time (Shennan et al. 2013), and the artefacts in SPD plots due to radiocarbon calibration curves (Williams 2012; Weninger et al. 2015). First, we reduce the potential bias of oversampling specific site-phases by aggregating uncalibrated radiocarbon dates from the same site that are within 100 years of each other and dividing by the number of dates that fall in this bin. Once this is done for all sites, the probabilities from each bin are summed: in our case, 726 radiocarbon dates have been grouped into 375 bins. This procedure ensures that each site-phase is equally weighted. Nevertheless, it is important to bear in mind that this approach could underestimate real population because it does not take account of the size of the site (dates from the same site and phase are lumped, whether the site is Rome or a small farmstead). In other words this approach adopts the pessimistic, or at least conservative, view that the intensity of radiocarbon dates for certain site phases comes from biases in the intensity of investigation rather than the larger size of the site in that phase. Following previous work (Williams 2012; Weninger et al. 2015) demonstrating that normalised calibrated dates produce abrupt, artificial peaks in SPDs at steep portions of the radiocarbon calibration curve (throughout we have used IntCal13, Reimer et al. 2013), we have opted to work in what follows with unnormalised dates.

Finally, an exponential null model representing taphonomic site loss through time and expected population increase going forward has been fitted to the observed SPD in order to produce a 95\% critical envelope (composed of 1,000 random SPDs) and statistically test if the observed pattern significantly departs from this model (for a detailed explanation of the method see Timpson et al. 2014, 555-556). Deviations above and below the 95\% limits of the envelope respectively indicate periods of population growth and decline greater than expected. Because $5 \%$ of the observed SPD 
could fall outside the confidence interval by pure chance, a global p-value has also been calculated in order to assess the area of the observed SPD outside the confidence envelope. It is worth pointing out that this value takes into account the overall shape of the SPD and, therefore, it is not unusual to have global p-values that are not statistically significant even when positive or negative local deviations are detected.

\subsection{Archeological settlement data and probabilistic approaches}

In our analysis, we used a resolution of 56 time steps each lasting 200 years, over a slight broader chronological range starting with period $t_{1}(10,000-9,800 \mathrm{BC})$ and ending with period $t_{56}(800-1000$ AD) to avoid edge effects. Then, we calculated the site count and summed the estimated site sizes for each time step in order to assess how the population changes across time every 200 years. This approach has been broadly used by archaeologists but can be problematic given the temporal uncertainty of archaeological data and the varying accuracy of different types of artefacts (e.g. pottery) in dating site-phases and periods. In fact, typo-chronological schemes defined by archaeological cultures can produce site-phases sometimes spanning several thousand years if dated by long-lived pottery types or surface material alone. Fig. 2 shows the frequency per 200-year timestep of 10,971 site occupation phases. The site-phases have different time spans according to their respective dating precision: longer time spans and higher uncertainty occur when the dating is based on artefacts with little diagnostic value and in contrast shorter time spans when uncertainty is lower - these time spans, it should be emphasised, are not the same as the actual longevity of the site in the past. Figure 2 makes it clear that most site-phases (around 5,000 of them) have a time span equal to or lower than 200 years. Nevertheless, other site-phases have a much longer time spans (up to 2,000 or 3,000 years) due to the low precision dating of some artefacts. The ones showing a time span of three thousand years are typically those recorded as Neolithic (Table 1) in the gazetteer of site and excavation reports.

In order to address this issue of temporal uncertainty while at the same time making use of all the chronological information in the archaeological data, we have adopted a probabilistic, 'aoristic' approach (see previous applications in Ratcliffe 2000; Johnson 2004; Crema et al. 2010, 1118-1121; Crema 2012, 446-448; Koláŕ et al. 2016; Orton at al. 2017). The method builds on the assumption that the total probability of an archaeological event (site occupation phase in our case) within a given time span is 1 , which indicates an absolute certainty that the site was in use in that time span. If we then divide by the length of the site's chronological range we can represent the probability of existence for each temporal block (implicitly therefore adopting a default uniform assumption). Put simply, using time-steps of 200 years, a site-phase ranging from 2200 to $1400 \mathrm{BC}$ has an aoristic weight of 0.25 for each time-step (2200-2000, 2000-1800, 1800-1600, 1600-1400; see Fig. 3a). Instead, a site-phase with a shorter time-span ranging from 2000 to $1600 \mathrm{BC}$ has an aoristic weight of 0.5 for each time-step and so on (2000-1800, 1800-1600; Fig. 3b). Having assigned such weights to each site, we can then sum them all in order to obtain the aoristic sum for each temporal block (Fig. 3).

Aoristic weights change when you modify the temporal resolution of the analysis (aoristic weights would be lower with time-steps of 100 years). Such aoristic analysis typically also assumes a uniform probability distribution (as noted above), which means that each year has the same probability of being the one in which the archaeological event occurred. Thus, an issue arises when a large sample of archaeological events with the same time-span occurs within the same temporal block. This results in homogeneous patterns, where large numbers of sites begin and end at the same time, because of the temporal structure of the data. While it is often difficult to judge the likely longevity of an individual site without considerable amounts of absolute dating, it is often evident that site durations are shorter than their assign chronological ranges. To mitigate this 
tension between wide chronological uncertainties and narrower likely site durations, we can use Monte Carlo methods to generate randomised start dates for sites with low-resolution information (see Crema 2012, 450-451; Kolář et al. 2016, 518-519; Orton et al. 2017, 5-6), using two slightly different methods: (1) a date is randomly drawn from a uniform distribution corresponding to the relevant chronological range of the site-phases concerned (Fig. 4a); (2) we adopt the same approach but draw the start date conditional on the shape of the relevant portion of the radiocarbon SPD (see below) so that sites are more likely to be chosen from periods of high radiocarbon probability density (Fig. 4c). This latter method has the advantage of using more information and indicating how closely the settlement data can agree in principle with the radiocarbon data, but it also builds in an element of circularity if comparisons are being made with the radiocarbon SPD results. Then, to the start date drawn by one of the methods above, we also add a site duration randomly generated from a normal distribution with a mean of 200 years and standard deviation of 50 years. This typical duration was chosen to correspond to the modal site phase lengths exihibited in fig 2 and offer clear contrast for those periods where uncertainties are much larger (e.g. 1000 years), but clearly the choice of mean expected site duration is slightly arbitrary and would best be informed by a wider range of evidence. In any case, this approach (Fig. $4 \mathrm{~b}$ and $4 \mathrm{~d}$ ) allows us to deal with those sitephases having a coarser resolution and time spans ranging over thousands of years. We can then simulate multiple time series and generated a 95\% critical envelope for all randomised start dates and durations of site occupation phases. The width of the envelope is indicative of the degree of temporal uncertainty in site occupation through time. The resulting probabilistic distributions of site frequencies through time, based on the aoristic sums and Monte Carlo simulations, provide useful comparisons with the raw site frequency data and the summed settlement sizes.

\section{Results}

\subsection{Summed Probability Distribution of Radiocarbon Dates}

Figure 5 shows the SPD of 726 radiocarbon dates from $7500 \mathrm{BC}$ to $500 \mathrm{AD}$, for both normalised and unnormalised dates with the former producing more artificially spiky probability distributions at steeper portions of the radiocarbon calibration curve as noted above. Despite our stated preference for the summing of unnormalised dates, it should be apparent that the overall pattern of SPDs does not differ substantially in either case in this instance. Figure 5c shows the (unnormalised) SPD of the data compared with a 95\% envelope for an exponential null model. Deviations above and below the null model respectively represent population growth or decline beyond that expected under a long-term exponential trend (and/or greater or lesser long-term taphonomic effects). The results show a significant overall departure of the observed SPD (black solid line) from the theoretical envelope of the exponential model $(\mathrm{p}=0.001)$. Significant population growth occurs during the Late Neolithic/Eneolithic ( 3.2-2.8 ka BC; 2.6-2.4 ka BC) and population decreases, although not significantly, between 2.2-1.7 ka BC. A further dramatic increase of population is indicated during the Final Bronze Age and Early Iron Age (1.1-0.8 ka BC). After this period, the radiocarbon population proxy gradually decreases until the fall of the Roman Empire.

\subsection{Archaeological site counts and sizes}

Figure 6 shows the frequency per 200-year time-block of 10,971 site occupation phases. In this analysis, five different versions of a proxy derived from archaeological settlement data have been used to model population dynamics over the long run: raw site counts, summed settlement area, aoristic sum, randomised site start date and duration (uniform assumption) and randomised site start date and duration (SPD-weighted assumption). The results for all five approaches show an increase in population at the beginning of the Neolithic ( $\sim 6 \mathrm{ka} \mathrm{BC})$ and peaks during the Late Neolithic ( 3.5 ka BC), the Eneolithic ( 2.3-2.1 ka BC), the Middle Bronze Age (1.7-1.5 ka BC), the Recent Bronze Age/Early Iron Age (1.1-0.7 ka BC), and the Late Republican/Early Imperial Roman period (100 BC-AD 100). These peaks are punctuated by population stagnation between $3.0-2.4 \mathrm{ka} \mathrm{BC}$ and 
2.1-1.8 ka BC, and population declines between 4.8-4.4 ka BC and 2.4-2.1 ka BC. Overall, all proxies show similar trends in terms of relative change of population through time between $7.5 \mathrm{ka}$ $\mathrm{BC}$ and $500 \mathrm{AD}$ (see below for a quantitative comparison). However, a striking difference among these five versions occurs between 1200 and 1000 BC where the site count, the aoristic weight and the randomised site start date values all show a slight decrease but the summed estimated size of settlements increases strongly (Fig. 6b). This reflects a pattern of settlement nucleation during the Early Iron Age (1020/950 - 750/725 BC), which resulted in the concentration of population in a smaller number of larger sites. Finally, from a long-term perspective, it seems that the population of central Italy started increasing dramatically in the Final Bronze Age and further peaked during the Roman Period between 300 BC and AD 200 (Fig. 6a).

\subsection{Comparing all population proxies}

Despite the different chronological resolution of the radiocarbon dates and the site occupation periods, the overall demographic trends appear roughly similar, and several points of convergence can be detected. In particular, all proxies suggest a first increase of population at the beginning of the Neolithic ( $6000 \mathrm{BC})$ and a further growth during the Late Neolithic and Eneolithic (see Fig. 7). A noticeable difference occurs at $2.3 \mathrm{ka} \mathrm{BC}$ when the raw site count and the summed site sizes both peak, while the radiocarbon SPD looks flat and both the aoristic weight and the randomised duration drop (Fig. 7). However, any perceived peak here is in fact an artefact of the temporal uncertainty in the occupation period of a number of sites broadly dated as Bronze Age (2.3-1.0 ka $\mathrm{BC})$ in the archaeological survey and excavation reports. More generally, this is because under conditions of considerable temporal uncertainty, the site raw count will tend to overestimate the population in a given time-span. All proxies comfortably converge in depicting a dramatic increase of population between $1.1 \mathrm{ka}$ and $0.8 \mathrm{ka} \mathrm{BC}$. A noticeable difference in the demographic trends appears during the Roman Period (500 BC-AD 500), where the SPD of radiocarbon dates declines (Fig. 5) and massively underestimates a widely-agreed and widely-evidenced boom in population at this time (Fig. 6a). This is due to reliance by most Roman archaeologists on traditional typochronological schemes defined by coins and fine ware pottery for dating as opposed to the use of radiocarbon dating.

\section{Discussion}

Our study provides what is, to our knowledge, a first application of a multi-proxy approach for assessing population dynamics in central Italy on a long-term perspective from the Mesolithic to the fall of the Roman Empire. We have built a large archaeological dataset consisting of 726 radiocarbon dates and 10,971 occupation phases from 7,383 sites in order to contribute to the current debate about the validity of different methods for reconstructing demographic trends, with further attention to methodological management of radiocarbon calibration effects, investigativebiases and temporal uncertainty in archaeological settlement data. Overall, the archaeological radiocarbon SPD and the various versions of the settlement proxy produced broadly similar demographic trends (Fig. 7). Pairwise Pearson's correlations among all proxies is statistically significant for the period from 7.5 to $0.8 \mathrm{ka} \mathrm{BC}$, ranging in magnitude between 0.53 and 0.98 (Fig. 8). Unsurprisingly given the evidence for settlement nucleation as population increases in the later periods, there is not a significant linear correlation between site counts and summed settlements size $(\mathrm{r}=0.23)$ : an increase or decrease in site numbers can correspond to an increase or decrease in estimated summed settlement size. In particular, the results show a broad agreement in the demographic trends produced by the SPD of radiocarbon dates and the other five related settlement indices, confirming that the former one can be regarded as a robust proxy for modelling population fluctuations through time, at least up to $800 \mathrm{BC}$ (see Fig. 7). In effect, a non-systematic sample of radiocarbon dates collected from a few hundred sites can mimic a quasi-random sample of occupation phases. However, as we have seen, the picture becomes misleading from $800 \mathrm{BC}$ 
onwards because archaeologists working in these periods usually rely on traditional pottery-based relative chronologies.

Unlike the radiocarbon dates, the other five proxies derived from archaeological settlement data provide a better coverage both chronologically and spatially in the area under investigation, as they are the results of intensive and extensive archaeological surveys carried out in Latium and Tuscany. Their cross-comparison is not only useful for defining population fluctuations through the full timerange of the study but also for detecting change in spatial settlement patterns when nucleation occurred in the form of an extreme concentration of population in a few large centres during the Early Iron Age (1020/950-725 BC). Thus, during the Final Bronze Age, we have 287 sites measuring a total size of 300 hectares (Fig. 9), while in the Early Iron Age there 212 sites measuring a total size of 1,200 hectares (Fig. 9). There is therefore a weak correlation between site counts and summed settlement sizes ( $\mathrm{r}=0.23$, Fig. 8), contrasting with a higher value $(\mathrm{r}=0.59)$ between those two proxies up to the Final Bronze Age (1175/1150-1020/950 BC). In other words, we need the summed site area information, as well as the various measures based on site counts if we are to arrive at a valid picture. The main drawbacks of the archaeological settlements, as data, are their coarse chronological resolution in comparison with the radiocarbon dates.

All proxies show an increase of population in the early Neolithic ( 6.0-5.5 ka BC) when compared with the population level in the earlier Late Mesolithic (Fig. 7). This increase seems, therefore, to be associated with the earliest adoption of farming economies and a much more stationary population settled in permanent houses and villages (Barker 1975, 144-147; Malone 2003, 267-269; Robb 2007, 26). A further substantial increase of population observable in all proxies occurs in the second half of the fourth millennium BC and results in two peaks during the Eneolithic (3.2-2.8 ka and 2.6-2.4 ka BC) punctuated by a population decline between 2.8-2.6 ka BC (Fig. 5c and Fig.7). In this period, communities started living in settlements greater than one hectare in size and based on more intensive mixed economies (agriculture, hunting, herding) comprising specialized techniques in the cultivation of different kinds of cereals and pulses (see Celant 2000; Anzidei and Carboni 2009; Anzidei et al. 2010, 342). At first glance, the second population peak occurring during the Eneolithic at $2.5 \mathrm{ka} \mathrm{BC}$ in the radiocarbon SPD seems to be shifted by 200 years from the one observed in the site count and the summed settlement size data (2.3 ka BC; see Fig. 7). This could be a result of the difference in temporal resolution between the SPD of radiocarbon dates and the archaeological settlement data, but regardless, it is likely that the peak at $2.3 \mathrm{ka} \mathrm{BC}$ in the site count and summed estimated settlement size data is an artefact of temporal uncertainty in archaeological site-phases broadly dated to the Bronze Age and assigned to a long time span (2300$1000 \mathrm{BC}$ ). This is likely to overestimate the number of sites that effectively were occupied at the beginning of the Early Bronze Age. In fact, the aoristic weight data and the randomised site start dates do not report any such peak (see Fig. 5b and 7). In contrast, the two peaks observable in the SPD of radiocarbon dates between 3.2-2.8 ka BC and 2.6-2.5 ka BC show a reasonable match with ones in the time-series of the aoristic sum (cf. Fig. 5b and 7). All six lines of evidence show a decrease of population between 2.2-1.7 ka BC that could be related to less favourable climatic conditions although further work would be needed to explore this possibility thoroughly for the Italian case (Weninger et al. 2009; Wiener 2014; Jung and Weninger 2015).

After $1.7 \mathrm{ka} \mathrm{BC}$, all measures show gradual population growth, which peaked dramatically during the Final Bronze Age and the Early Iron Age (1.2-0.9 ka BC). The divergence between the summed settlement size and the other settlement measures in this latter period is explained by the radical changes occurring in settlement patterns between the Final Bronze Age (ca. 1175-1020/950 BC) and the beginning of the Early Iron Age (ca. 1020/950-750/25 BC). This period sees the abandonment of small-sized dispersed villages (generally 2-3ha) located in open positions or on 
small hilltops and the occupation of a smaller number of sites of larger sizes (50-100 ha) distributed over the lowlands and plateaus (Peroni 2000; Fulminante 2014, 44-47; Alessandri 2015 and 2016; Redhouse and Stoddart 2011; Stoddart 2016; Fig. 9). This process culminated in full-scale urbanisation and early-state societies during the Late Iron Age (750/725-580 BC) and Archaic period (580-480 BC), when the political landscape was fragmented into several city-states located at an average distance of $15-25 \mathrm{~km}$. The dramatic growth of population occurring in the Final Bronze Age (1175-1020/950 BC) and Early Iron Age (1020/950-750 BC) also had a significant impact on the landscape cover with an abrupt increase in cultivated trees (e.g. olive, walnut, chestnut) rather than a simple increase in landscape openness/forest loss (Alessio et al. 1986; Magri and Sadori 1999; Mercuri et al. 2002). During the Roman period (500 BC-AD 500), the population boomed massively (Fig. 6b) and reached a peak in the Early and Middle Imperial Period (30 BCAD 150; see also Witcher 2008 and 2009). Then, from the middle second century AD onwards the population gradually decreased, concomitantly with a wave of epidemics (e.g. the Antonine plague) and endemic civil warfare, and reached pre-Roman period levels at the fall of the Roman Empire (see Scheidel 2002; Turchin and Nefedov 2009, 233-239; Witcher 2009).

\section{Conclusions}

Time series of summed radiocarbon dates and of settlement data (e.g. counts and/or estimated settlement size) have been the most popular proxies in archaeology for modelling population dynamics through time. Nevertheless, with a few exceptions these proxies have rarely been assessed comparatively. In this paper, we therefore adopted a multi-proxy approach, comparing several different archaeological indices to assess the extent to which they corroborate or diverge from one another. The resulting six time series and their cross-comparison allow us to explore the strengths and weaknesses of different lines of evidence and develop a better understanding of demographic trends in central Italy between the Mesolithic and the fall of the Roman Empire. The overall agreement between the radiocarbon SPD dates and the settlement-based proxies corroborates the use of the former as a good indicator of changes in prehistoric population density in archaeological research, despite the limitations pointed out in this paper and also emphasised by other authors. Overall, there is general agreement among all proxies in identifying an increase of population in the Early Neolithic, in the Eneolithic, in the Final Bronze Age/Iron Age and a last demographic boom during the Roman Period. Although not the focus of this paper, the further advantage of these different kinds of demographic proxy is that that can be juxtaposed with palaeoclimate data, pollen records of land cover and/or similar data from neighbouring Italian regions to compare and contrast patterns of coupled human-environmental dynamics at both local and supra-regional scales.

\section{Acknowledgements}

This research was funded by the Leverhulme Trust grant number RPG-2015-031 for the project Changing the face of the Mediterranean: land cover and population since the advent of farming. The analysis for generating SPDs of radiocarbon dates has been performed in R v. 3.3.1 by using the rcarbon package developed by Andrew Bevan and Enrico Crema (accessible at https://github.com/ahb108/rcarbon).

\section{Appendix A. Supplementary data and code}

Data, source codes and scripts used in this work can be found in the journal data paper by Palmisano et al. (in press) and UCL Discovery online repository: 10.14324/000.ds.1575442 


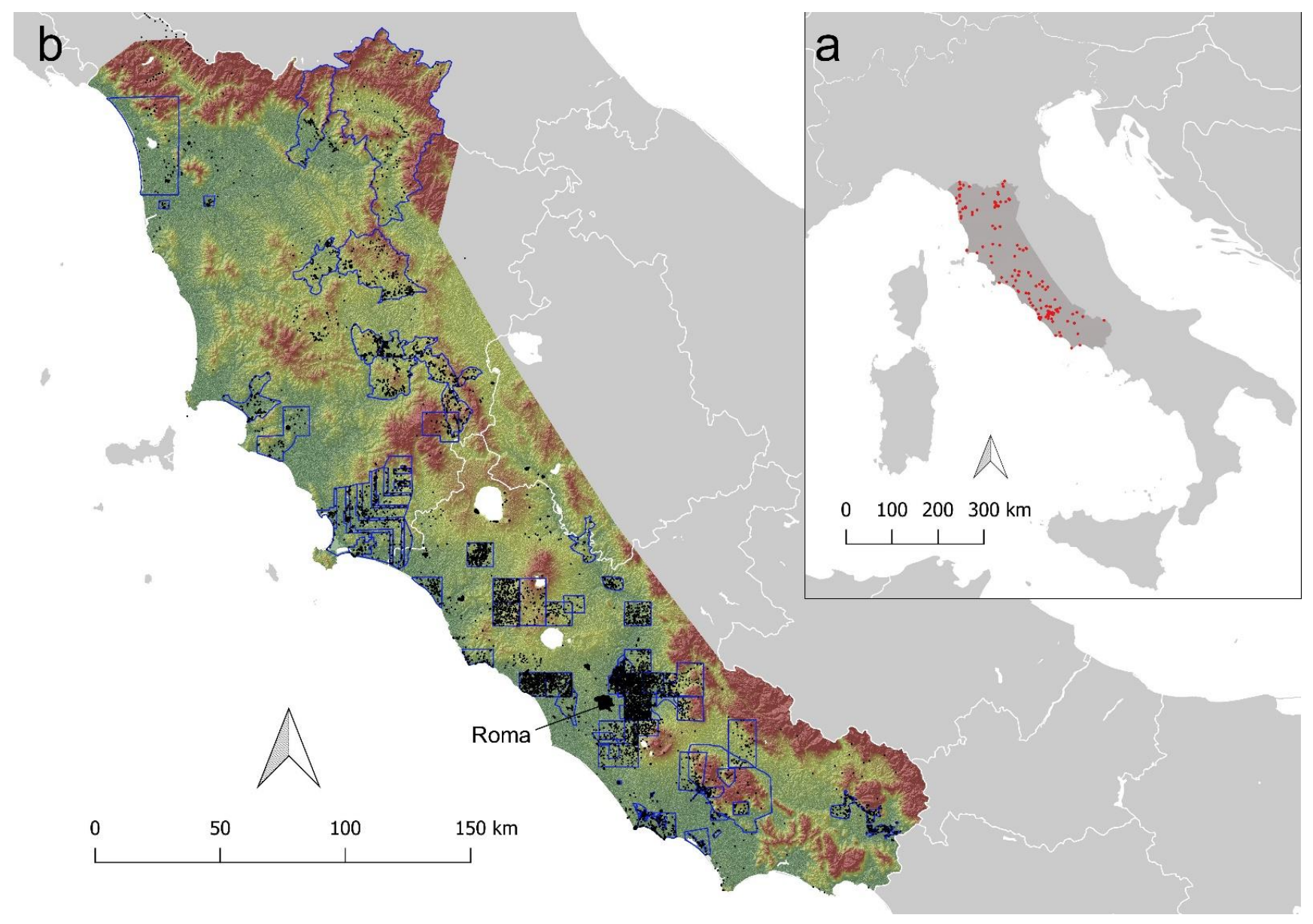

Figure 1. Map showing the a) distribution of radiocarbon samples and b) sites (the blue polygons indicate the bundary of the archaeological surveys).

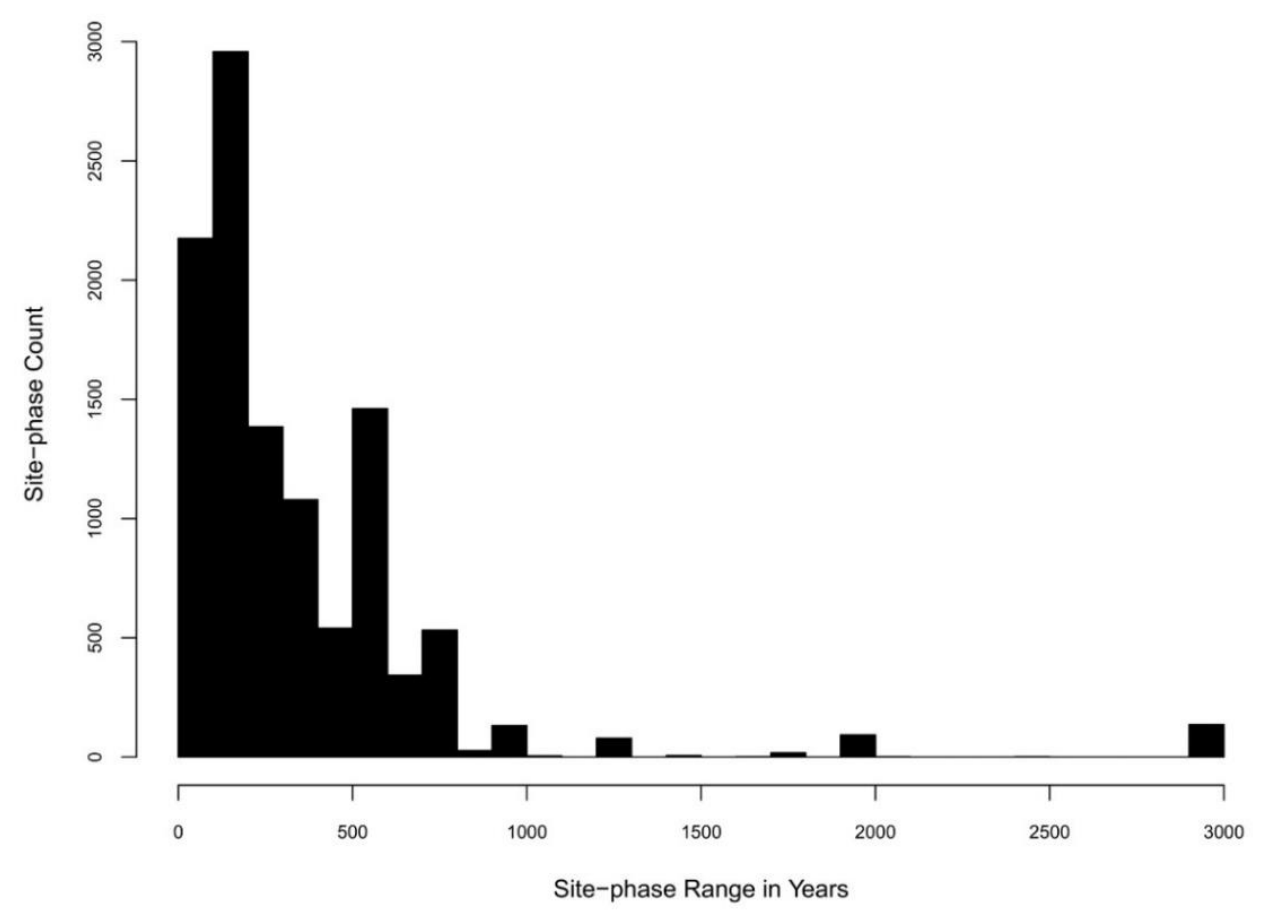

Figure 2. Histogram showing the frequency of site-phases per time-span. 


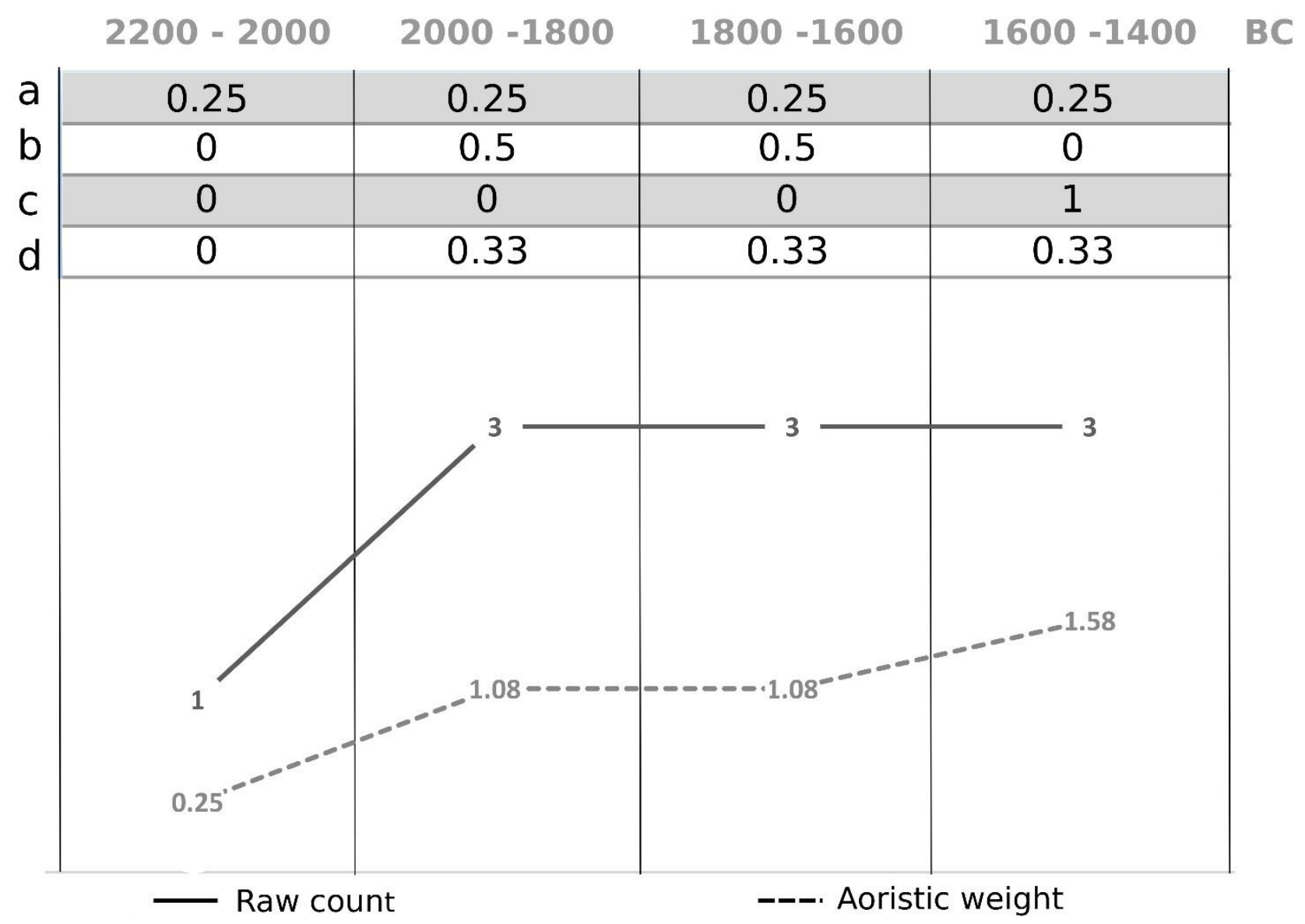

Figure 3. Four different site-phases (a-d) with varying chronological ranges indicated horizontally by the length of their temporal blocks. Each 200 years time-step reports an aoristic weight, which represents the probability of existence of a site within each temporal block. The aoristic sum (dashed line) is plotted vs. the raw count of sites (solid line). 


\section{$6000 \mathrm{BC}$}

(a)

(b)

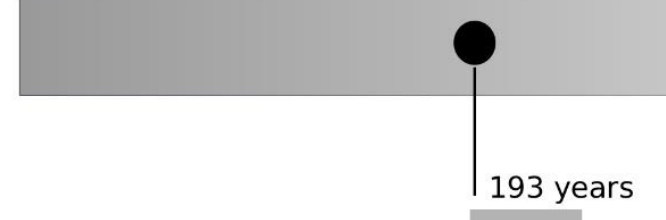

\section{$4730 \quad 4537 \mathrm{BC}$}

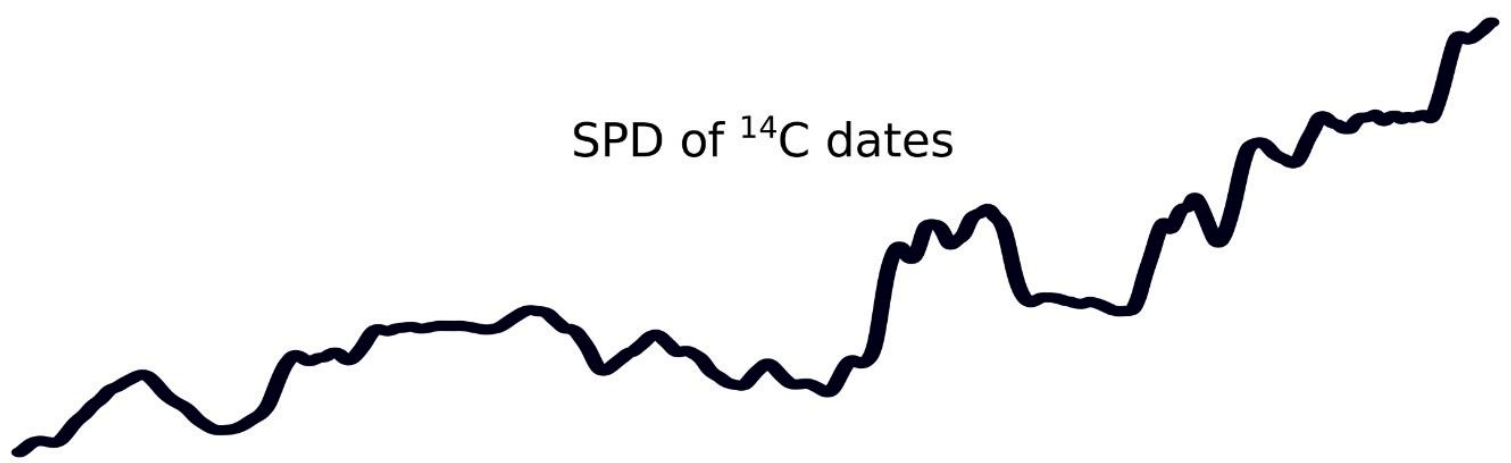

(c)

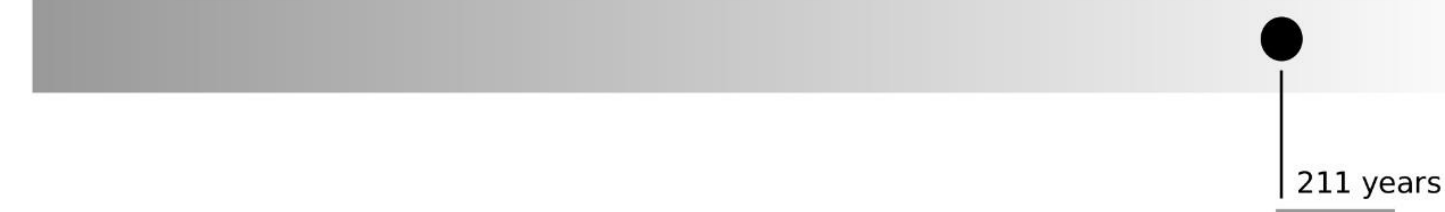

(d)

Figure 4. Randomised start date of sites: a) a date is randomly drawn within the time-span of a given sitephase with a uniform probability distribution or c) with a probability weighted by the SPD of radiocarbon dates, and b-d) a sites duration randomly generated from a normal distribution with a mean of 200 years and a standard deviations of 50 years is added to the drawn date. 


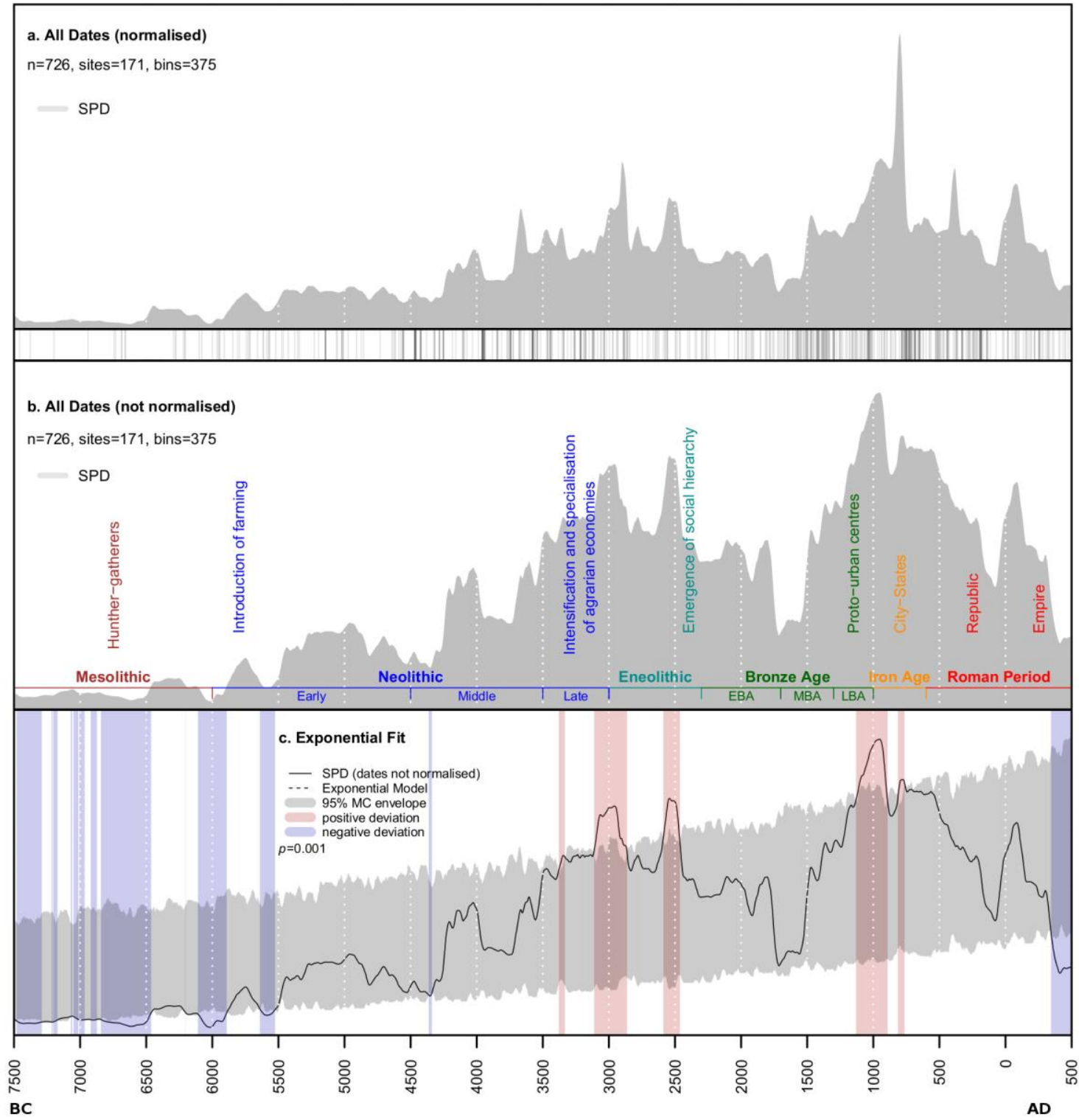

Figure 5. Summed Probability Distribution (SPD) of a) normalised and b) unnormalised calibrated radiocarbon dates, and (c) unnormalised (solid line) vs. a fitted exponential (95\% confidence grey envelope). Blue and red vertical bands indicate respectively chronological ranges within the observed SPD deviates negatively and positively from the null model. 

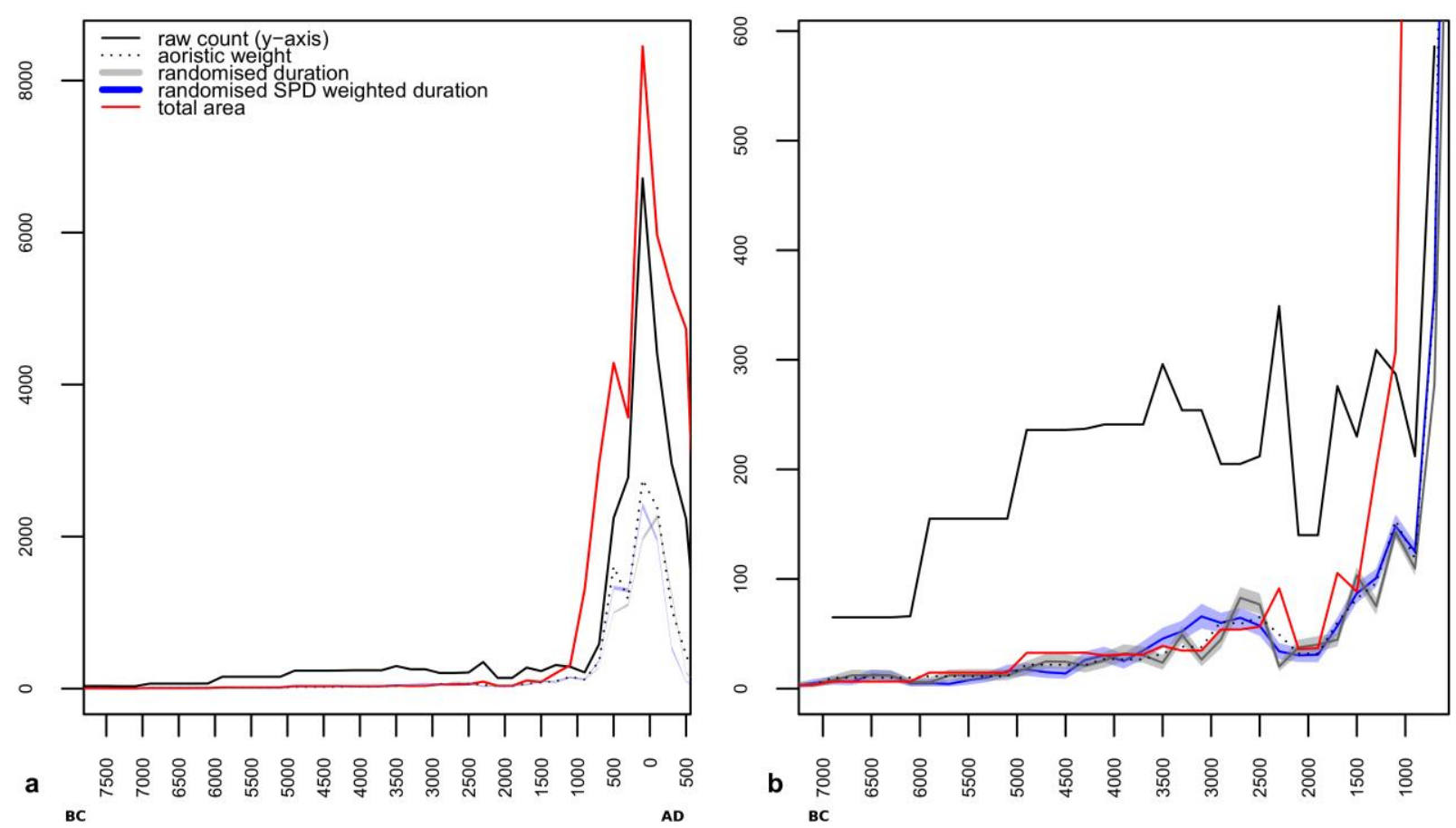

Figure 6. a) Comparison of sites raw count (solid line), summed estimated settlement size (red line), aoristic sum (dashed line), randomised start date of sites (grey envelope), and SPD weighted randomised start date of sites (blue envelope) from $7.5 \mathrm{ka} \mathrm{BC}$ to $500 \mathrm{AD}$. b) Inset of population change between 7.0 and $0.8 \mathrm{ka} \mathrm{BC}$.

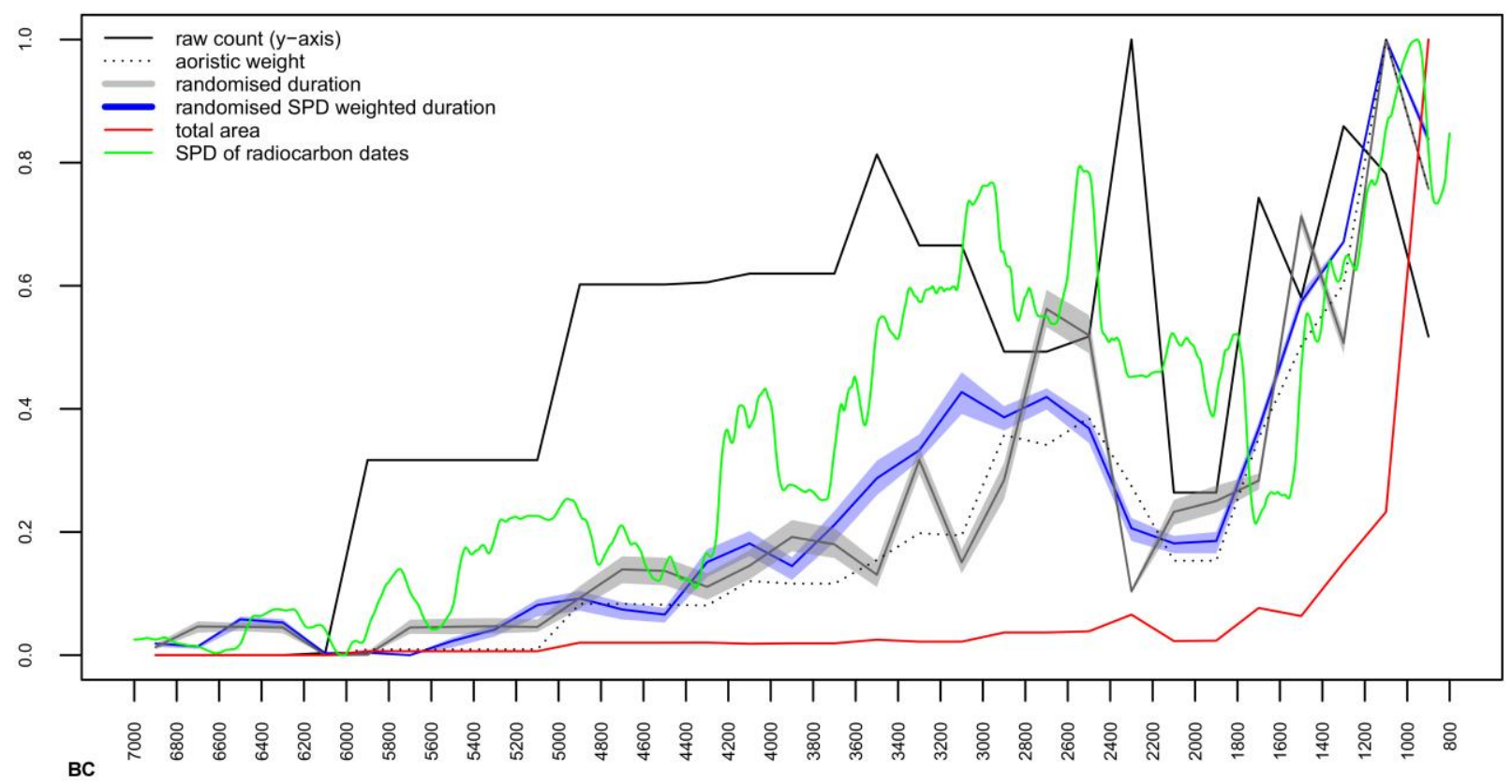

Figure 7. Comparison of all archaeological proxies: sites raw count (solid line), summed estimated settlement size (red line), aoristic sum (dashed line), randomised duration of sites with uniform probability (grey envelope), SPD weighted randomised duration of sites weighted (blue envelope), and SPD of radiocarbon dates (green line) from $7.0 \mathrm{ka} \mathrm{BC}$ to $800 \mathrm{BC}$. All values have been normalised between 0 and 1 . 


\section{Color Key}
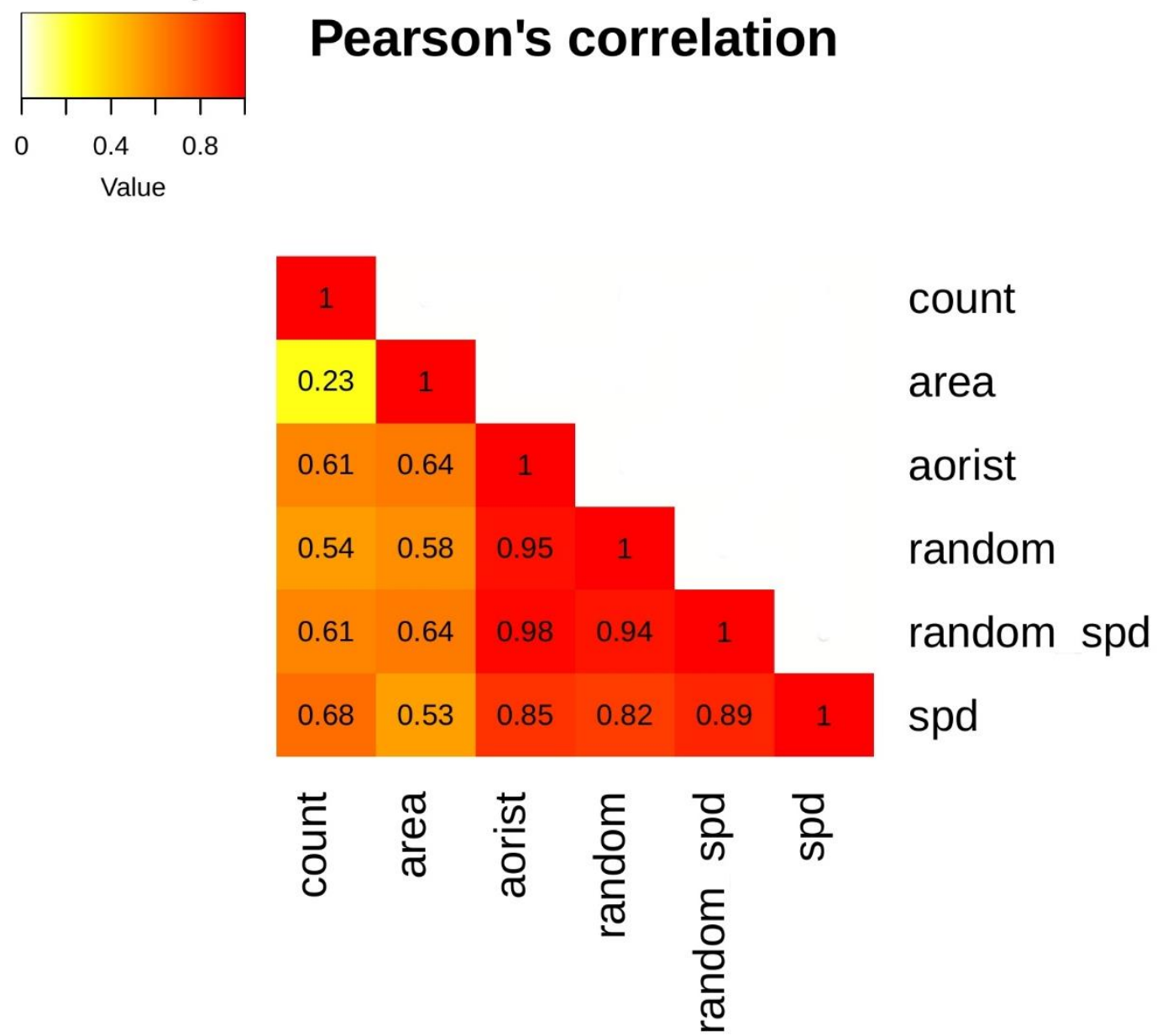

Figure 8. Pairwise Pearson's correlations between all archaeological proxies. The red-yellow scale values represent correlation values, with dark red representing the better fit and yellow the worse fit results. 

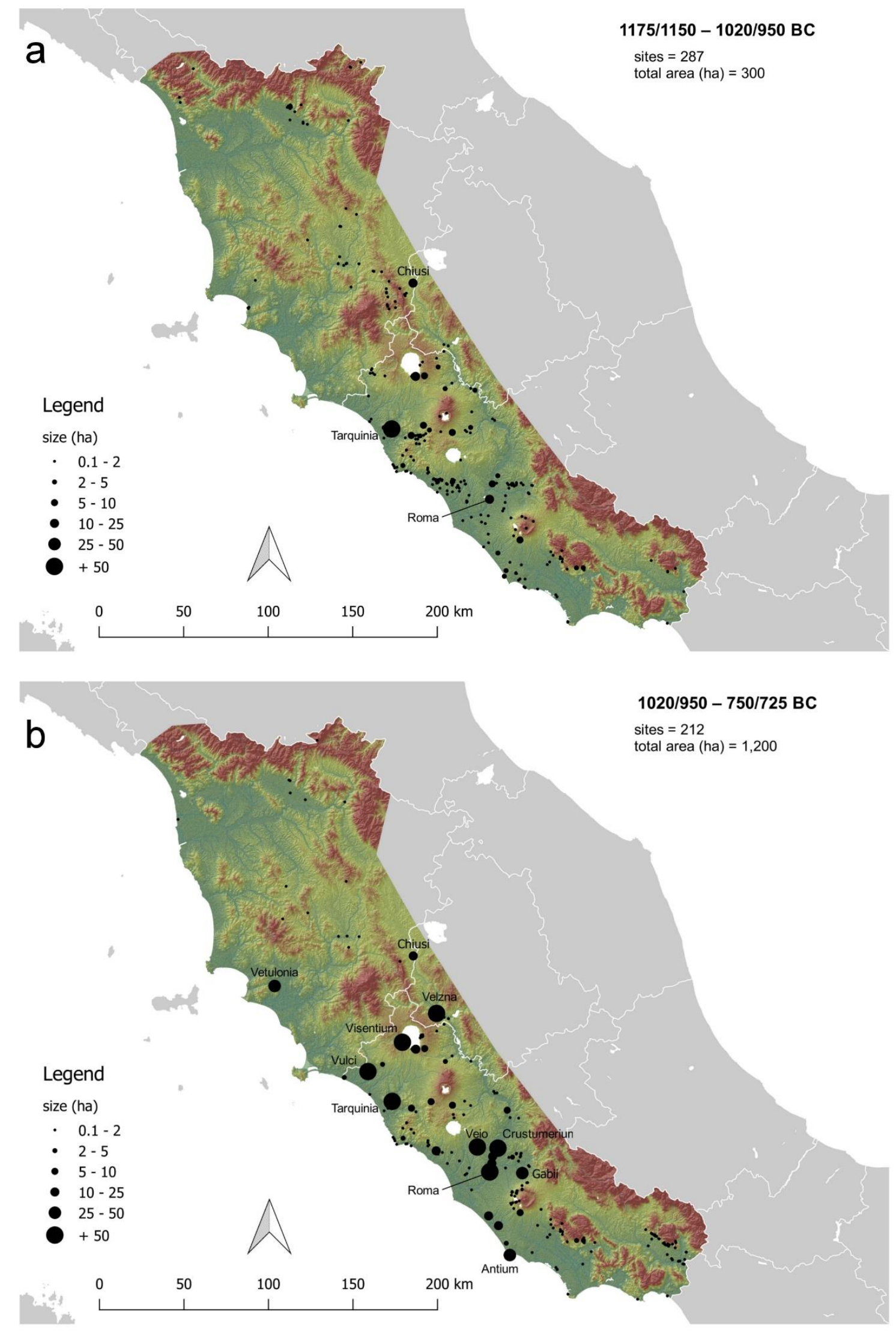

Fig. 9. Settlements distribution and estimated size during the Final Bronze Age (a) and the Early Iron Age (b). 


\section{References}

Adams, R., M., 1965. Land Behind Baghdad: A History of Settlement on the Diyala Plains. Chicago: Chicago University Press.

Adams, R., M., 1981. Heartland of Cities: Surveys of Ancient Settlement and Land Use On the Central Floodplain at the Euphrates. Chicago: Chicago University Press.

Alessandri, L., 2015. Exploring territories: bubble model and minimum number of contemporary settlements. A case study from Etruria and Latium Vetus from the Early Bronze Age to the Early Iron Age. Origini XXXVII, 175-199.

Alessandri, L., 2016. Hierarchical and federative polities in protohistoric Latium Vetus. An analysis of Bronze Age and Early Iron Age settlement organization. In: P. Attema, J. Seubers, and S. Willemsen (eds.), Early states, territories and settlements in protohistoric Central Italy. Corollaria Crustumina 2. Groningen: Groningen Institute of Archaeology.

Alessio, M., Allegri, L., Bella, F., Calderoni, G., Cortesi, C., Dai Pra, G., De Rita, D., Esu D., Follieri, M., Improta, S., Magri, D., 1986. 14C dating, geochemical features, faunistic and pollen analyses of the uppermost $10 \mathrm{~m}$ core from Valle di Castiglione (Rome, Italy). Geologica Romana 25, 287-308.

Allen, H. D., 2001. Mediterranean Ecogeography. Harlow: Prentice Hall/Pearson Education.

Ammermann, A. J., 1985. Plow-Zone Experiments in Calabria, Italy. Journal of Field Archaeology $12,33-40$.

Anzidei, A. P., and, Carboni, G., 2009. Il comprensorio dei Colli Albani ed aree limitrofe durante il Neolitico e l'Eneolitico. In: L. Drago Troccoli (ed.), Il Lazio dai Colli Albani ai Monti Lepini tra preistoria ed età moderna. Roma: Edizioni Quasar, 89-98.

Anzidei, A.P., Barbaro, B., Carboni, G., Castagna, A., Celant, A., Egidi, R., Favorito, S., Malvone, M. and Spadoni, D., 2010. Geomorphological and environmental transformations during the recent prehistory. A reconstruction of the landscape and the peopling of the territory south-east of Rome. The Colli Albano Volcano Special Publications of IAVCEI 3, 339-353.

Anzidei, A. P., and, Zarattini, A., 2007. Il Neolitico e 1'Eneolitico nel Lazio centro-meridionale. Aspetti culturali e scelte insediamentali. In: Istituto Italiano di Preistoria e Protostoria, Atti della XL Riunione Scientifica, Strategie di Insediamento fra Lazio e Campania in Eta' Preistorica e Protostorica, Roma, Napoli, Popmei, 30 Novembre - 3 Dicembre 2005. Firenze: Istituto Italiano di Preistoria e Protostoria, 79-100.

Attema, P., Burgers, G.J. and Leusen, M.V., 2010. Regional pathways to complexity: settlement and land-use dynamics in early Italy from the Bronze Age to the Republican period. Amsterdam: Amsterdam University Press.

Balsera, V., Bernabeu Aubán, J., Costa Caramé, M., Díaz del Río, P., García Sanjuán, L. and Pardo, S., 2015. The Radiocarbon Chronology of Southern Spain's Late Prehistory (5600-1000 Cal BC): a Comparative Review. Oxford Journal of Archaeology 34(2), 139-156. 
Barker, G., 1975. Prehistoric territories and economies in Central Italy. In: E. Higgs (ed.), Palaeoeconomy. Cambridge: Cambridge University Press, 111-175.

Barker, G. and Stoddart, S., 1994. The Bronze Age of central Italy-c. 2000-900 BC. In: C. Mathers and S. Stoddart (eds.), Development and Decline In the Mediterranean Bronze Age. Sheffield: John Collis Publications, 145-165.

Binford, L.R., 1968. Post-Pleistocene adaptations. In: Binford, S.R., and Binford, L.R. (eds.), New perspectives in archaeology. Chicago: Aldine Publishing Company, 313-341.

Bocquet-Appel, J. P. 2002. Paleoanthropological traces of a Neolithic demographic transition. Curr.Anthropol. 43:637-647.

Bocquet-Appel, J.-P., Naji, S., Linden, M.V., Kozlowski, J.K., 2009. Detection of diffusion and contact zones of early farming in Europe from the space-time distribution of 14C dates. Journal of Archaeological Science 36, 807-820.

Boserup, E., 1965. The condition of agricultural growth. The Economics of Agrarian Change under Population Pressure. London: Allan and Urwin,

Brantingham, P. J., Surovell, T. A. and Waguespack, N. M., 2007. Modeling postdepositional mixing of archaeological deposits. Journal of Anthropological Archaeology 26, 517-540.

Butlin, R.A., and Roberts, N. (eds.), 1995. Ecological relations in historical times: human impact and adaptation. Oxford: Blackwell.

Carneiro, R.L., 1962. Scale analysis as an instrument for the study of cultural evolution. Southwestern Journal of Anthropology, 18(2), 149-169.

Cassidy, L.M, Martiniano, R., Murphy, E.M., Teasdale, M.D., Mallory, J., Hartwell, B., and Bradley, D.G. Neolithic and Bronze Age migration to Ireland and establishment of the insular Atlantic genome. PNAS 2016113 (2) 368-373.

Celant, A., 2000. Nuovi dati archeobotanici su ambiente e agricoltura nel Neolitico del Lazio: un esempio dalla Campagna Romana. Atti del Convegno di Studi La Neolitizzazione tra Oriente ed Occidente, Museo Friulano di Storia Naturale, 355 - 363.

Cherry, J. F., 1983. Frogs Round the Pond: Perspectives on Current Archaeological Survey Projects in the Mediterranean Region. In: Keller D. R. and Rupp D. W. (eds.), Archaeological Survey in the Mediterranean Region. Oxford: British Archaeological Reports, 375-416. Cohen, M.N., 1977. Food crisis in prehistory: overpopulation and the origins of agriculture. New Haven: Yale University Press.

Cifani, G., 2002. Aspects of Urbanization and Ethnic Identity in the Middle Tiber valley. In: P. A. J. Attema, G. J. Burgers, E. van Joolen, M. van Leusen, and B. Mater (eds.). New Developments in Italian Landscape Archaeology. Oxford: Archaeopress (BAR International Series, 1091), 220-228. 
Contreras, D. A, and Meadows J., 2014. Summed radiocarbon calibrations as a population proxy: a critical evaluation using a realistic simulation approach. Journal of Archaeological Science 52, 591-608.

Costantini, L., and Costantini Biasini, L., 2007. Economia Agricola del Lazio a sud del Tevere tra Bronzo antico e Bronzo medio. In: Istituto Italiano di Preistoria e Protostoria, Atti della XL Riunione Scientifica, Strategie di Insediamento fra Lazio e Campania in Eta' Preistorica e Protostorica, Roma, Napoli, Popmei, 30 Novembre - 3 Dicembre 2005. Firenze: Istituto Italiano di Preistoria e Protostoria, 787 - 801.

Crema, E. R., Bevan, A., and Lake, M., 2010. A probabilistic framework for assessing spatiotemporal point patterns in the archaeological record. Journal of Archaeological Science 37, 11181130.

Crema, E.R., 2012. Modelling temporal uncertainty in archaeological analysis. Journal of Archaeological Method and Theory 19(3), 440-461.

Crema, E.R., Habu, J., Kobayashi, K. and Madella, M., 2016. Summed Probability Distribution of 14 C Dates Suggests Regional Divergences in the Population Dynamics of the Jomon Period in Eastern Japan. PloS one 11(4), p.e0154809.

Demjan, P. and D. Dreslerov 2016. Modelling distribution of archaeological settlement evidence based on heterogeneous spatial and temporal data, Journal of Archaeological Science 69, 100-109

Di Giuseppe, H., 2005. Realtà micro-regionali a confronto sulle due sponde del Tevere tra l'età arcaica e repubblicana. In: P.Attema, A.J.Nijboer, A.Zifferero (eds.), Communities and Settlements from the Neolithic to the Early Medieval Period. Proceedings of the 6th Conference of Italian Archaeology (Groningen, April 15-17 2003). BAR International Series 1452 (II). Oxford: Archaeopress, 1056-1067.

Downey, S.S., Bocaege, E., Kerig, T., Edinborough, K. and Shennan, S., 2014. The neolithic demographic transition in Europe: correlation with juvenility index supports interpretation of the Summed Calibrated Radiocarbon Date Probability Distribution (SCDPD) as a valid demographic proxy. PloS one 9(8), p.e105730.

Drennan, R.D., Berrey, C.A. and C. E., Peterson, 2015. Regional Settlement Demography in Archaeology. New York: Eliot Werner Publications.

Feinman, G. and Neitzel, J., 1984. Too many types: An overview of sedentary prestate societies in the Americas. Advances in archaeological method and theory 7, 39-102.

Feinman, G.M., 2011. Size, complexity, and organizational variation: A comparative approach. Cross-Cultural Research, 45(1), 37-58.

Flohr, P., Fleitmann, D., Matthews, R., Matthews, W. and Black, S., 2016. Evidence of resilience to past climate change in Southwest Asia: Early farming communities and the 9.2 and 8.2 ka events. Quaternary Science Reviews 136, 23-39. 
French, J.C., 2015. The demography of the Upper Palaeolithic hunter-gatherers of Southwestern France: A multi-proxy approach using archaeological data. Journal of Anthropological Archaeology 39, 193-209.

French, J.C., and Collins, C., 2015. Upper Palaeolithic population histories of Southwestern France: a comparison of the demographic signatures of $14 \mathrm{C}$ date distributions and archaeological site counts. Journal of Archaeological Science 55, 122-134.

Fugazzola Delpino, M. A., D’Eugenio, G., and Pessina, A., 1993. "La Marmotta" (Anguillara Sabazia, Roma). Scavi 1979. Un abitato perilacustre di eta' neolitica. Bullettino di Paletnologia Italiana 48, 181-342.

Fulminante, F., 2014. The urbanisation of Rome and Latium Vetus: from the Bronze Age to the Archaic era. Cambridge: Cambridge University Press.

Fyfe, R.M., Roberts, N. and Woodbridge, J., 2010. A pollen-based pseudo-biomisation approach to anthropogenic land cover change. The Holocene 20, 1165-71.

Gallant, T.W., 1986. Background noise and site definition: a contribution to survey methodology. Journal of Field Archaeology 13, 403-418.

Gennaro, F., and, Peroni, R., 1986. Aspetti regionali dello sviluppo dell'insediamento protostorico nell'Italia centro-meridionale alla luce dei dati archeologici e ambientali. Dialoghi di Archeologia $3,193-200$.

Gregg, S. A., Kintigh, K. W. and Whallon, R., 1991. Linking Ethnoarchaeological Interpretation and Archaeological Data: The Sensitivity of Spatial Analytical Methods to Postdepositional Disturbance. In: E. M. Kroll and T. D. Price (eds.), The Interpretation of Archaeological Spatial Patterning, New York: Plenum Press, 149-196.

Guidi, A., and Piperno, 1993. Italia preistorica. Bari: Laterza

Hirth, Kenneth G., 1978. Problems in Data Recovery and Measurement in Settlement Archaeology. Journal of Field Archaeology 5, 125-131.

Johnson, I., 2004. Aoristic analysis: seeds of a new approach to mapping archaeological distributionst hrough time. In: K. F. Ausserer, W. Börner, M. Goriany, \& L. Karlhuber-Vöckl (Eds.), [Enter the past] the E-way into the four dimensions of cultural heritage: CAA2003. BAR International Series 1227. Oxford: Archaeopress, 448-452.

Jung, R., and Weninger, B., 2015. Archaeological and environmental impact of the $4.2 \mathrm{ka}$ cal BP event in the central and eastern Mediterranean. In: H. Meller, H. W. Arz, R. Jung \& R. Risch (eds.), 2200 BC - Ein Klimasturz als Ursache für den Zerfall der Alten Welt? 2200 BC - A climatic breakdown as a cause for the collapse of the old world? Halle (Saale): Tagungen des Landesmuseums für Vorgeschichte Halle, 205-234.

Kolář, J., Macek, M., Tkáč, P. and Szabó, P., 2016. Spatio- Temporal Modelling As A Way to Reconstruct Patterns of Past Human Activities. Archaeometry 58(3), 513-528. 
Langgut, D., Adams, M.J. and Finkelstein, I., 2016. Climate, settlement patterns and olive horticulture in the southern Levant during the Early Bronze and Intermediate Bronze Ages (c. 3600-1950 BC). Levant 48(2), 117-134.

Maher, L.A., Banning, E.B. and Chazan, M., 2011. Oasis or mirage? Assessing the role of abrupt climate change in the prehistory of the southern Levant. Cambridge Archaeological Journal 21(01), $1-30$.

Lewit, T., 1991. Agricultural productivity in the Roman economy A.D. 200-400. Oxford: Tempus Reparatum.

Magri, D. and Sadori, L., 1999. Late Pleistocene and Holocene pollen stratigraphy at Lago di Vico, central Italy. Vegetation history and archaeobotany 8(4), 247-260.

Malone, C., 2003. The Italian Neolithic: a synthesis of research. Journal of World Prehistory 17(3), 235-312.

Martini, F., 2001. Paleolitico Superiore e Mesolitico. In: Istituto Italiano di Preistoria e Protostoria, Atti della XXXIV Riunione Scientifica: preistoria e protostoria della Toscana : Firenze, 29 settembre - 2 ottobre 1999. Firenze: Istituto Italiano di Preistoria e Protostoria, 41-56.

Mayewski, P.A., Rohling, E.E., Stager, J.C., Karlen, W., Maasch, K.A., Meeker, L.D., Meyerson, E.A., Gasse, F., van Kreveld, S., Holmgren, K., Lee-Thorp, J., Rosqvist, G., Rack, F., Staubwasser, M., Schneider, R.R., and Steig, E.J., 2004. Holocene climate variability. Quaternary Research 62, 243-255.

Mercuri, A.M., Accorsi, C.A. and Mazzanti, M.B., 2002. The long history of Cannabis and its cultivation by the Romans in central Italy, shown by pollen records from Lago Albano and Lago di Nemi. Vegetation History and Archaeobotany, 11(4), 263-276.

Michczyńska, D.J., Pazdur, A., 2004. Shape analysis of cumulative probability density function of radiocarbon dates set in the study of climate change in late glacial and holocene. Radiocarbon 46 (2), $733-744$.

Michczyńska, D.J., Michczyński, A., Pazdur, A., 2007. Frequency distribution of radiocarbon dates as a tool for reconstructing environmental changes. Radiocarbon 49 (2), 799 - 806.

Michczyński, A. and Michczyńska, D.J., 2006. The effect of PDF peaks' height increase during calibration of radiocarbon date sets. Geochronometria, 25, 1-4.

Naroll, R., 1956. A Preliminary Index of Social Development. American Anthropologist 58 (4), 687-715.

Netting, R.M., 1993. Smallholders, householders: farm families and the ecology of intensive, sustainable agriculture. Stanford: Stanford University Press.

Ortman, S.G., Cabaniss, A.H., Sturm, J.O. and Bettencourt, L.M., 2015. Settlement scaling and increasing returns in an ancient society. Science advances 1(1), p.e1400066. 
Orton, D., Morris, J. and Pipe, A., 2017. Catch Per Unit Research Effort: Sampling Intensity, Chronological Uncertainty, and the Onset of Marine Fish Consumption in Historic London. Open Quaternary, 3(1), 1-20.

Palmisano, A., Bevan, A., and Shennan, S., in press. Regional Demographic Trends and Settlement Patterns in Central Italy: Archaeological Sites and Radiocarbon Dates. Journal of Open Archaeology Data.

Peregrine, P.N., 2004. Cross-cultural approaches in archaeology: comparative ethnology, comparative archaeology, and archaeoethnology. Journal of Archaeological Research 12(3), 281309.

Peroni, R., 1996. L'Italia alle soglie della storia. Bari: Laterza.

Peroni, R., 2000. Formazione e sviluppo dei centri protourbani medio-tirrenici. In A. Carandini and R. Cappeili (eds.), Roma, Romolo, Remo e la fondazione delta città, catalogo della mostra. Milan: Electa, 26-30.

Plog, S., Plog, F., and Wait, W., 1978. Decision Making in Modern Surveys. In: M. B. Schiffer (ed.), Advances in Archaeological Method and Theory. New York: Academic Press, 384-421.

Sanders, W.T., and, Price, B.J., 1968. Mesoamerica: the evolution of a civilization (Vol. 149). New York: Random House.

Rajala, U., 2013. The concentration and centralization of late prehistoric settlement in central Italy: the evidence from the Nepi Survey. Papers of the British School at Rome 81, 1-38.

Ratcliffe, J. H., 2000. Aoristic analysis: the spatial interpretation of unspecifed temporal events. International Journal of Geographical Information Science 14, 669-679.

Redhouse, D. I., and Stoddart, S., 2011. Mapping Etruscan State Formation. In: N. Terrenato, and D. C. Haggis (eds.), State formation in Italy and Greece: Questioning the Neoevolutionist Paradigm: Oxford: Oxbow Books, 162-178.

Reimer, P.J., Bard, E., Bayliss, A., Beck, J.W., Blackwell, P. G., Bronk-Ramsey, C., et al., 2013. IntCal13 and Marine13 radiocarbon age calibration curves 0-50,000 Years cal BP. Radiocarbon 55(4), 1869-1887.doi:10.2458/azu_js_rc.55.16947

Rick, J.W, 1987. Dates as Data: An examination of the Peruvian radiocarbon record. American Anitquity 52, 55-73.

Robb, J., 2007. The early Mediterranean village: agency, material culture, and social change in Neolithic Italy. Cambridge University Press.

Roper, D. C., 1976. Lateral Displacement of Artefacts Due to Plowing. American Antiquity 41, 372375.

Sanders, W. T., 1965. The cultural ecology of the Teotihuacan Valley. University Park, Pa.: Dept. of Sociology \& Anthropology, Pennsylvania State University. 
Sanders, W. T, Parsons, J. R., and Santley, R. S., 1979. The Basin of Mexico. New York: Academic Press.

Sanders, W.T. and Price, B., 1968. Mesoamerica. The Evolution of a Civilization. New York: Random House

Scheidel, W., 2002. A model of demographic and economic change in Roman Egypt after the Antonine plague. Journal of Roman Archaeology 15, 97-114.

Shennan, S., 2000. Population, culture history, and the dynamics of culture change. Current Anthropology 41, 811-835.

Shennan, S., 2001. Demography and cultural innovation: a model and its implications for the emergence of modern human culture. Cambridge Archaeological Journal 11 (1), 5-16.

Shennan, S., 2009. Evolutionary demography and the population history of the European early Neolithic. Human Biology 81(3), 339-355.

Shennan, S., Edinborough, K., 2007. Prehistoric population history: from the late Glacial to the late Neolithic in Central and Northern Europe. Journal of Archaeological Science 34, 1339-1345.

Shennan, S., Downey, S.S., Timpson, A., Edinborough, K., Colledge, S., Kerig, T., Manning, K., Thomas, M.G., 2013. Regional population collapse followed initial agriculture booms in midHolocene Europe. Nature Communications 4. http://dx.doi.org/10.1038/ncomms3486

Stoddart, S., 2016. Power and Place in Etruria. In: M. Fernández-Götz, and D. Krausse (eds.), Eurasia at the Dawn of History: Urbanization and Social Change. Cambridge: Cambridge University Press, 304-318.

Surovell, T.A., Brantingham, P.J., 2007. A note on the use of temporal frequency distributions in studies of prehistoric demography. Journal of Archaeological Science 34, 1868-1877.

Surovell, T.A., Byrd Finley, J., Smith, G.M., Brantingham, P.J., Kelly, R., 2009.Correctingtemporal frequency distributions for taphonomic bias. Journal of Archaeological Science 36, 1715-1724.

Timpson, A., Colledge, S., Crema, E., Edinborough, K., Kerig, T., Manning, K., Thomas, M.G. and Shennan, S., 2014. Reconstructing regional population fluctuations in the European Neolithic using radiocarbon dates: a new case-study using an improved method. Journal of Archaeological Science $52,549-557$.

Tallavaara, M., Pesonen, P. and Oinonen, M., 2010. Prehistoric population history in eastern Fennoscandia. Journal of Archaeological Science 37(2), 251-260.

Thorndycraft, V.R., Benito, G., 2006. The holocene fluvial chronology of Spain: evidence from a newly compiled radiocarbon database. Quaternary Science Reviews 25, 223-234.

Torfing, T., 2015. Layers of assumptions: A reply to Timpson, Manning, and Shennan. Journal of Archaeological Science 63, 203-205. 
Tozzi, C., 2012. Il Paleolitico e il Mesolitico dell'Etruria dall'Arno al Tevere. In: N. Negroni Catacchio (ed.), L'Etruria del Paleolitico al Primo Ferro, Lo stato delle Ricerche. Atti del Decimo Incontro di Studi, Valentano (VT) - Pitignano (GR), 10-12 Settembre 2010. Milano: Centro di Studi di Preistoria e Archeologia, 75-91.

Turchin, P., and Nefedov, S.A., 2009. Secular cycles. Princeton: Princeton University Press.

Vanzetti, A., 2002. Some Current Approaches to Protohistoric Centralization and Urbanization in Italy. In: P. A. J. Attema, G. J. Burgers, E. van Joolen, M. van Leusen, and B. Mater (eds.), New Developments in Italian Landscape Archaeology. Oxford: Archaeopress (BAR International Series, 1091), 36-59.

Walsh, K., 2014. The archaeology of Mediterranean landscapes. Human-Environment Interaction from the Neolithic to the Roman Period. Cambridge: Cambridge University Press.

Wandsnider, L., 1998. Regional Scale Processes and Archaeological Landscape Units. In: A. F. Ramenofsky and A. Steffen (eds.), Unit Issues in Archaeology: Measuring Time, Space, and Material. Utah: University of Utah Press, 87-102.

Weninger, B., Clare, L., Rohling, E., Bar-Yosef, O., Böhner, U., Budja, M., Bundschuh, M., Feurdean, A., Gebe, H.G., Jöris, O. and Linstädter, J., 2009. The impact of rapid climate change on prehistoric societies during the Holocene in the Eastern Mediterranean. Documenta praehistorica 36, 7-59.

Weninger, B., Clare, L., Jöris, O., Jung, R. and Edinborough, K., 2015. Quantum theory of radiocarbon calibration. World Archaeology, 47(4), 543-566.

Wiener, M.H., 2014. The interaction of climate change and agency in the collapse of civilizations ca. 2300-2000 BC. Radiocarbon, 56(4), S1-S16.

Wigand, P. and McCallum, M., 2017. The Varying Impact of Land Use and Climate in Holocene Landscape Dynamics in the Mezzogiorno. Journal of Mediterranean Studies 3(2), 121-150.

Williams, A.N., 2012. The use of summed radiocarbon probability distributions in archaeology: a review of methods. Journal of Archaeological Science, 39(3), 578-589.

Williams, A.N., Ulm, S., Goodwin, I., Smith, M., 2010. Hunter-gatherer response to late Holocene climatic variability in northern and central Australia. Journal of Quaternary Science 25 (6), 831838.

Witcher, R. E., 2005. The Hinterlands of Rome: Settlement Diversity in the Early Imperial Landscape of Regio VII Etruria. In: P. Attema, A. J. Nijboer, and A. Zifferero (eds.), Papers in Italian archaeology VI: communities and settlements from the Neolithic to the early Medieval period: proceedings of the 6th Conference of Italian Archaeology held at the Univrsity of Groningen, Groningen Institute of Archaeology, the Netherlands, April 15-17, 2003. Oxford: Archaeopress, pp. 1045-1055. 
Witcher, R.E., 2008. Regional Field Survey and the Demography of Roman Italy. In: L. de Ligt and S. Northwood (eds.), People, Land and Politics. Demographic Developments and the Transformation of Roman Italy, 300BC-AD14. Leiden: Brill, 273-303.

Witcher, R., 2009. The Middle Tiber Valley in The Imperial Period. In: F. Coarelli, and H. Patterson (eds.), Mercator Placidissimus, The Tiber Valley in Antiquity. New research in the upper and middle river valley. Roma: Edizioni Quasar, 467-486.

Woodbridge, J., Fyfe, R.M., Roberts, N., Downey, S., Edinborough, K. and Shennan, S., 2014. The impact of the Neolithic agricultural transition in Britain: a comparison of pollen-based land-cover and archaeological $14 \mathrm{C}$ date-inferred population change. Journal of Archaeological Science 51, 216-224.

Wright, H.T. and Johnson, G.A., 1975. Population, exchange, and early state formation in southwestern Iran. American Anthropologist, 77(2), 267-289. 